\title{
Geological assessment of the East Greenland margin
}

\author{
Michael B.W. Fyhn, Thorkild M. Rasmussen, Trine Dahl-Jensen, Willy L. Weng, \\ Jørgen A. Bojesen-Koefoed and Tove Nielsen
}

The East Greenland margin consists of a number of sedimentary basins, platforms and structural highs (Figs 1, 2). Due to the challenges imposed by the Arctic climate, the region is in an early stage of exploration, and knowledge of the geology and petroleum potential of the margin is limited. However, the significant prospectivity of the conjugated European North Atlantic margin and the nature of the NorthEast Greenland onshore geology prompt for future offshore exploration. The US Geological Survey thus highlighted the North-East Greenland margin in their latest assessment of the Arctic region (Gautier et al.2011). With a mean estimate of undiscovered recoverable oil, gas, and natural gas liquids of approximately 31 billion barrels of oil equivalents, the US Geological Survey ranked the North-East Greenland margin fourth in the entire Arctic region, only superseded by known producing petroleum provinces.

In preparation for the initial East Greenland licence rounds in 2012 and 2013 the Geological Survey of Denmark and Greenland gathers geological information on the margin necessary for the decision process of the Greenland authorities regarding exploration. Geophysical analyses complemented by well-data, onshore geology and information from the conjugated Atlantic margin form the backbone of the study. The East Greenland margin is covered by an open seismic grid supplemented by gravimetric and magnetic data. All existing 2D seismic, gravimetric and magnetic data are included in the current study. Most of the data are confidential. Restricted by the general confidential nature of the project, this paper aims to summarise the geology of the East Greenland margin based on the current and previous studies and to briefly assess some of the implications for the regional petroleum prospectivity.

\section{East Greenland offshore geology}

The East Greenland margin stretches almost $3000 \mathrm{~km}$ from Kap Farvel in the south to Nordostrundingen in the north (Fig. 1). In the south it is narrow, but north of Liverpool Land it begins to widen to more than $300 \mathrm{~km}$. The geology varies considerably along its length.

\section{East Greenland margin south of Shannon}

A continuous Paleocene-Eocene $(61-53 \mathrm{Ma})$ pre- to postbreak-up volcanic cover blankets almost the entire East Greenland margin between Kap Farvel and the island of Shannon (Fig. 1). Paleocene - Early Eocene magmatism re-

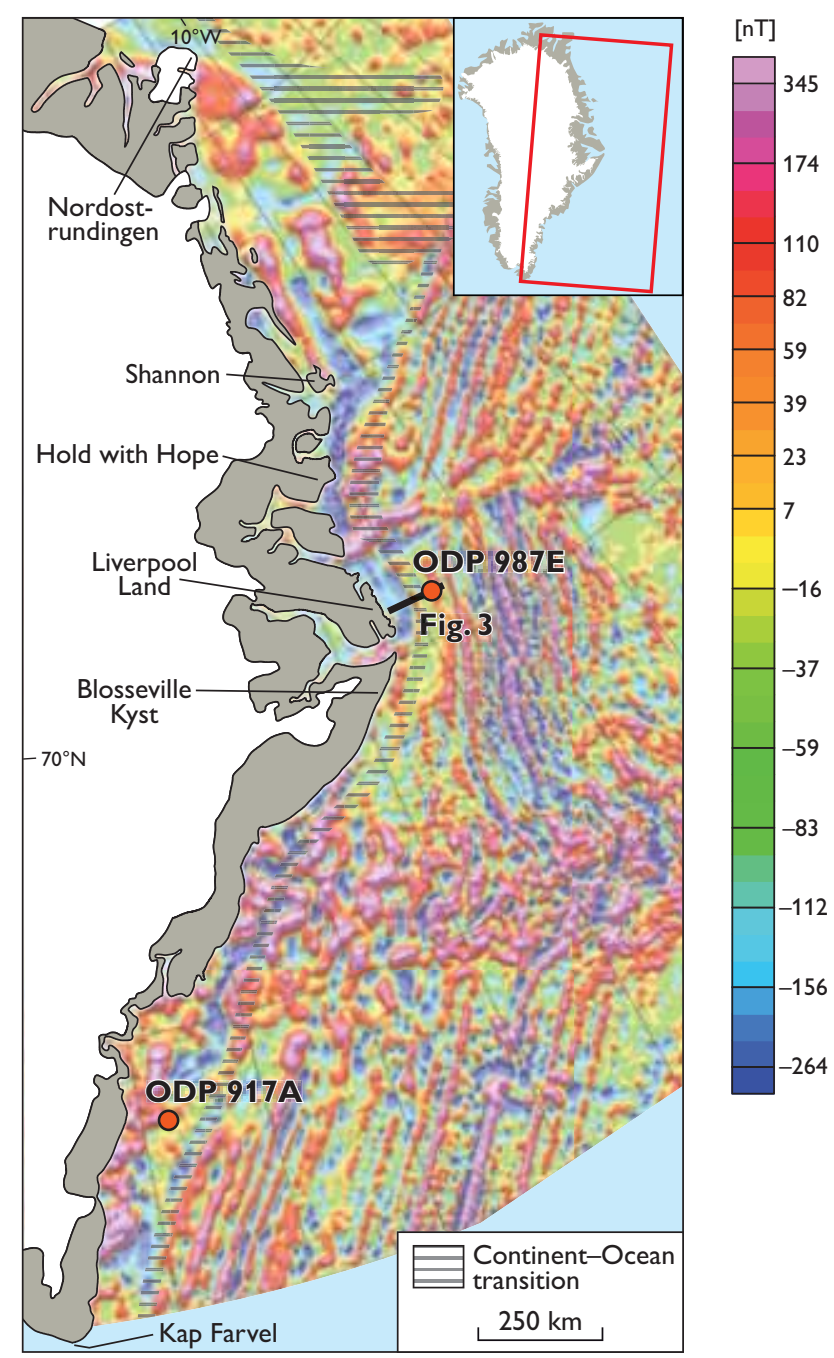

Fig. 1. The East Greenland margin from Kap Farvel to Nordostrundingen with offshore magnetic total field anomaly from the CAMP-GM compilation (Gaina et al. 2009). 
cords the trace of the Icelandic hotspot that induced magmatism along most of the proto-North Atlantic margin and likely led to continental break-up between Europe and Greenland.

Thick seaward-dipping reflection packages interpreted as basalt flows exist near the continent-ocean transition indicating the presence of a very thick basalt-dominated succession below the distal part of the margin (Fig. 3). Basalt successions several hundred metres to kilometres thick exist onshore central East and North-East Greenland. It is likely that similar and thicker Paleocene - Lower Eocene basalt successions cover large parts of the offshore margin judging from seismic data, wells and onshore analogies (Fig. 2).

Only the ODP well 917A offshore South-East Greenland penetrates the entire basaltic cover (Fig. 1; Larsen \& Saunders 1998). The well was drilled on the shoreward part of the margin and encountered $779.5 \mathrm{~m}$ of mainly basalts and

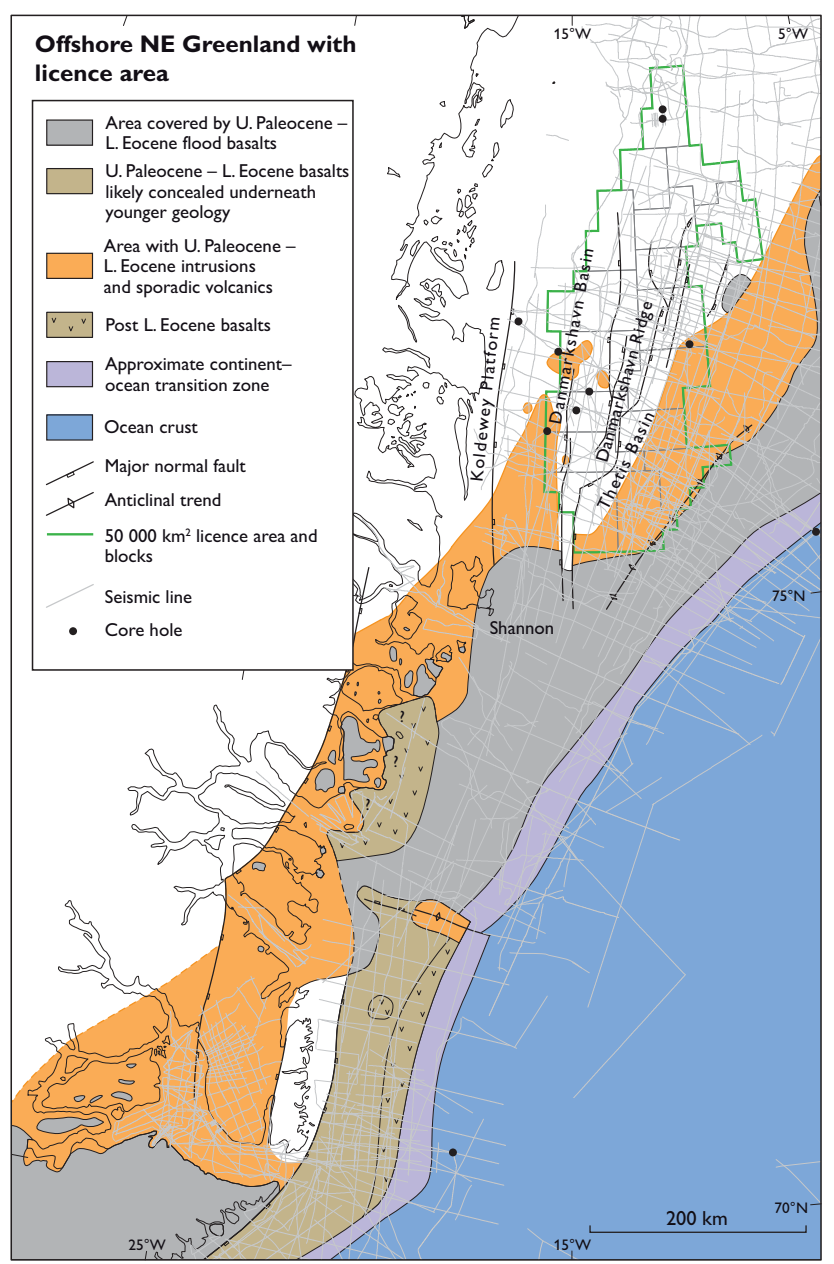

Fig. 2. The extent of massive volcanism along the North-East Greenland margin. Magmatism influenced areas up to $200 \mathrm{~km}$ north of the basalt cover as indicated by the heavily intruded part of the Thetis and Danmarkshavn Basins. thus documents the presence of a thick volcanic cover in the shoreward part of the margin that, according to seismic evidence, significantly thickens seawards.

Offshore Liverpool Land, the Paleocene/Eocene top-basalt surface is not clearly discernable on all seismic transects. However, this is probably due to the deep burial of the basalt succession beneath a thick post-basaltic cover. In the area offshore Hold with Hope, the presence of volcanics younger than the regional Upper Paleocene - Lower Eocene flood basalts is interpreted from seismic data (Fig. 2). These are likely to be genetically related to Middle Eocene - earliest Miocene magmatism observed immediately onshore.

Sub-basalt sediments. The Tertiary basalt cover generally impedes seismic imaging of the deeper geology. Offshore SouthEast Greenland, sub-basaltic acoustic velocities derived from refraction seismic data generally range from 4.5 to $6 \mathrm{~km} / \mathrm{s}$ increasing downwards (Hopper et al. 2003), which does not provide unequivocal evidence for regional, thick sub-basaltic sedimentary basins.

A sub-basaltic succession of deformed metasediments barren of fossils drilled in ODP well 917A was suggested to be Upper Cretaceous to Lower Paleocene in age, like onshore sediments farther north (Larsen \& Saunders 1998). However, the succession could also represent much older Caledonian metasediments formed in a foreland setting, comparable to onshore metasediments farther to the north and lying beneath the conjugated British margin.

Offshore North-East Greenland, Upper Palaeozoic Mesozoic deposits below the basalts are suggested by the presence of thick such deposits along the shore, immediately onshore and on the conjugated Norwegian North Atlantic margin. Moreover, a thick pre-basaltic sedimentary succession can be recognised offshore Shannon, continuing southwards below the basalts.

Post-Paleocene sediments. The Eocene and younger succession between Kap Farvel and Shannon attains thicknesses up to $c .3 \mathrm{sec}$ two-way travel time (TWT). The succession is absent or very thin shoreward, and over large areas, break-up volcanics and Upper Palaeozoic and Caledonian basement crop out at the seafloor.

Farther offshore, an Eocene and younger shelf progradation along most of the margin resulted in the build-up of the prominent modern shelf-slope that generally straddles the continent-ocean transition. The Blosseville Kyst Fault Zone along the Blosseville Kyst and its northern continuation the Liverpool Land Fault Zone downfault the break-up volcanic cover with up to 2 sec TWT (Fig. 2). Rifting along Blosseville Kyst and Livepool Land Fault Zones was likely 


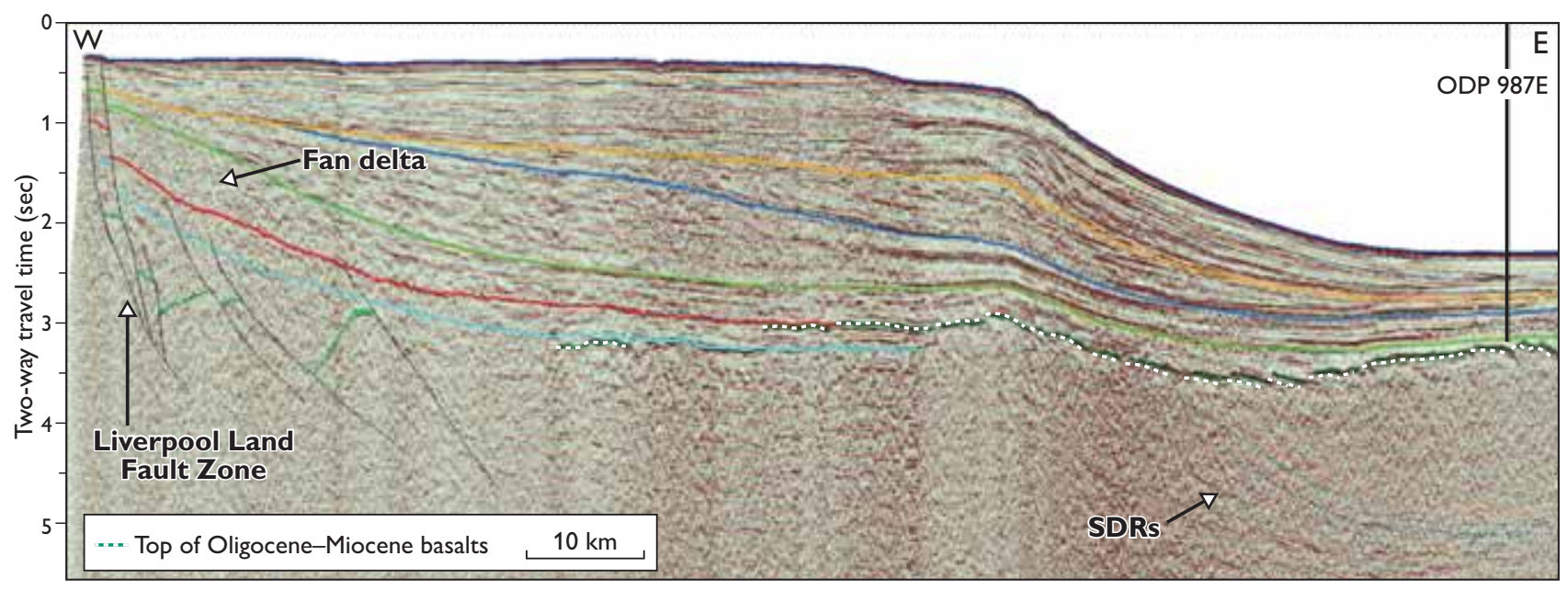

Fig. 3. An E-W seismic profile crossing the Liverpool Land Fault Zone and related syn-tectonic fan delta deposits and the continent-ocean transition indicated by seaward-dipping reflectors (SDRs). The ODP 987E well drilled Recent to Miocene strata and terminated slightly above the basalts.

associated with a westward jump of the spreading axis and the separation of the Jan Mayen microcontinent from central East Greenland during mid-Cenozoic time (Mjelde $e t$ al. 2008). Faulting mostly affected the lower part of the postbreak-up succession, and a significant syn-tectonic fan delta flanks the fault zones suggesting (?)Late Eocene/Oligocene to $c$. Early Miocene faulting (Fig. 3). Faults only penetrate the seafloor near the coast where erosion and non-deposition have prevented fault burial.

\section{East Greenland margin north of Shannon}

North of the island of Shannon, the landward edge of the basalt cover curves to the east and continues farther seawards to the north where a wide basalt belt fringes the continent-ocean transition (Fig. 2). This leaves the shelf area north of Shannon virtually unaffected by Tertiary flood basalts and thus permits fair to good seismic imaging of Paleocene and older successions. As a result, up to $c .10 \mathrm{sec}$ TWT several deep sediment-filled basins can be recognised north of Shannon that are likely to correspond to between 15 and $20 \mathrm{~km}$ of sedimentary infill.

The area can be structurally divided into the Danmarkshavn and Thetis Basins separated by the Danmarkshavn Ridge - a c. $300 \mathrm{~km}$ long rifted basement high (Fig. 2). The Danmarkshavn Basin is downfaulted relative to the Koldewey Platform to the west and the Danmarkshavn Ridge to the east. The Thetis Basin marks the oceanward part of the North-East Greenland margin that borders the North Atlantic oceanic crust. The depositional succession filling in the Thetis Basin may be of comparative thickness to that of the Danmarkshavn Basin, but there are significant differences in the geological development of the two basins.
The Koldewey Platform makes up an area of sedimentcovered, more shallow basement bridging the Danmarkshavn Basin and the onshore basement province. The Danmarkshavn Ridge stands in marked contrast to the deeply downfaulted Thetis Basin farther east. As the high degrades into fault blocks to the north, the ridge plunges and the structural separation of the Thetis and Danmarkshavn Basins crumbles.

Structural and stratigraphic development. The deepest deposits in the Danmarkshavn Basin and on the Danmarkshavn Ridge form a prominent syn-rift succession interpreted to be Devonian and Carboniferous in age (Hamann et al. 2005). The unit is located in a rift system often confined by lowangle extensional faults, which may reflect extensional reactivation of Caledonian thrust faults.

The syn-rift succession is overlain by a unit in the central and southern part of the Danmarkshavn Basin that has in places been mobilised into diapiric and pillow-like structures interpreted as salt kinetic features. The succession is interpreted as Lower Carboniferous to Early Permian deposits comparable to coeval sediments in the western part of the Barents Sea (Hamann et al. 2005).

The Late Palaeozoic successions are buried beneath an up to a few kilometres thick unit only moderately affected by syn-depositional faulting and interpreted as Upper Permian - Jurassic deposits. By analogy to the conjugated Atlantic margin and onshore geology, the Upper Permian - Jurassic succession is likely to contain a number of prominent source rock intervals. Of these the Upper Jurassic equivalent to the Kimmeridge Clay Formation may be of particular importance to potential petroleum systems in the region.

The top of the Jurassic is marked by a pronounced angular unconformity associated with the onset of Cretaceous rifting 
(Hamann et al. 2005). Cretaceous rifting resulted in several kilometres of downfaulting towards the Thetis Basin, and to a lesser extent also along the margins of the Danmarkshavn Basin. Consequently, the Danmarkshavn Ridge became an elevated rift-shoulder subject to erosion during most of the Cretaceous. In contrast, vast amounts of sediment were shed into the adjacent basins and kilometre-thick Cretaceous successions exist in the depocentres. Large fault- and anticlinal structures within Cretaceous and older successions formed in association with the Cretaceous extension. Many of these resemble structures hosting world-class oil and gas fields on the conjugate European Atlantic margin, thus boosting expectations for the North-East Greenland margin.

A change from fault-controlled subsidence concentrated along the basins to regional eastward tilting took place close to the Cretaceous/Tertiary boundary. The change resulted in flooding and burial of the Danmarkshavn Ridge during the Early Tertiary and instigated regional eastwards progradation across the basin areas.

Only modest volcanism, if any, took place across the basins north of Shannon. However, the southern Danmarkshavn and Thetis Basins were heavily intruded far north of the edge of the East Greenland basalt province, which degrades seismic imaging of the deepest stratigraphy over large areas. During mid-Tertiary time, sediment supply increased resulting in build-up and eastward progradation of a steep shelf-slope. This was likely caused by denudation of the East Greenland margin and the inner basin areas. As a result, the Lower Tertiary and Mesozoic deposits lie beneath the Plio/ Pleistocene sediments along the inner half of the North-East Greenland shelf.

\section{Implications for the petroleum prospectivity offshore East Greenland}

Assessment of the petroleum prospectivity along the SouthEast and central East Greenland margin is associated with considerable uncertainties. A sub-basaltic source rock seems to be a prerequisite for a working petroleum system along the margin, but the thick volcanic cover complicates analysis of the deeper geology. Regional presence of sub-basaltic basins is at present uncertain offshore South-East Greenland, which also makes the prediction of an effective petroleum system along this part of the margin uncertain. Farther north between Liverpool Land and Shannon the chances of sub-basaltic basins containing significant source-rock intervals are high. However, interpretation of the sub-basaltic structural style is problematic at present and the maturation history of potential source-rock intervals is uncertain, which complicates the prospectivity assesment.

Farther north, extreme sea-ice conditions are a major impediment to future exploration. In addition, Tertiary uplift and erosion as well as past glacial advances across the shelf may have affected the regional petroleum potential. However, the presence of large structures and the good chance of adequately matured source-rock intervals urge for further investigation. The highest density of structures is located along the flanks of the basins and across the Danmarkshavn Ridge, which are also the areas covered in the coming licence rounds (Fig. 2). Many of these structures are associated with significant potential direct hydrocarbon indicators, which may reflect the presence of significant petroleum accumulations offshore North-East Greenland. This is highly encouraging for further exploration in one of the last frontier areas on Earth.

\section{Acknowledgement}

The Bureau of Minerals and Petroleum, Nuuk, is acknowledged for funding.

\section{References}

Gaina, C., Werner, S.C. \& the CAMP-GM group 2009: Circum-Arctic mapping project - gravity and magnetic maps. Report 2009.010, 21 pp. Trondheim: Geological Survey of Norway.

Gautier, D.L. et al. 2011: Assessment of NE Greenland: prototype for development of Circum-Arctic resource appraisal methodology. In: Spencer, A.M. et al. (eds): Arctic petroleum geology. Geological Society Memoirs (London) 35, 663-672.

Hamann, N.E., Whittaker, R.C. \& Stemmerik, L. 2005: Geological development of the Northeast Greenland shelf. In: Doré, A.G. \& Vining, B.A. (eds): Petroleum geology: North-West Europe and global perspectives. Proceedings of the 6th Petroleum Geology Conference, 887-902. London: Geological Society.

Hopper, J.R., Dahl-Jensen, T., Holbrook, W.S., Larsen, H.C., Lizarralde, D., Korenaga, J., Kent, G.M. \& Kelemen, P.B. 2003: Structure of the SE Greenland margin from seismic reflection and refraction data: Implications for nascent spreading center subsidence and asymmetric crustal accretion during North Atlantic opening. Journal of Geophysical research 108, 2269, http://dx.doi.org/10.1029/2002JB001996

Larsen, H.C. \& Saunders, A.D. 1998: Tectonism and volcanism at the southeast Greenland rifted margin: a record of plume impact and later continental rupture. In: Saunders, A.D., Larsen, H.C. \& Wise, S.W. (eds): Proceedings of the Ocean Drilling Program Scientific results 152, 503-533.

Mjelde, R., Raum, T., Breivik, A.J. \& Faleide, J.I. 2008: Crustal transect across the North Atlantic. Marine Geophysical Research 29, 73-87. 